\title{
Narrative and Critical Imaginations in International Relations*
}

\author{
J. da S.C. de Oliveira \\ Pontifical Catholic University of Minas Gerais, Poços de Caldas, Brazil
}

\begin{abstract}
Narrative strategies have gained growing attention in IR. One key promise is mobilizing a diversity of interpretations and exploring the politics contestedness in ways that support the view of IR as focused on the multiplicity of the world(s) of international and global affairs. This article brings a broad map of the use of narrative approaches in IR and connects it with Edward Said's notion of "worldliness" in order to highlight the political aspects of writing and representation within academia. It situates this "narrative turn" within the complexities of a broader context of crisis in Eurocentric forms of knowledge and representation. In addition, it reveals a double movement of scholarly disenchantment and re-enchantment that signals towards the productivity of intellectual unease about representational practices and the place of the "I" voice in academic writing. Bearing in mind these reactions and shared pursuit of a more empathetic relationship between researcher and researched, scholars and the public in general, teachers and students, I thus briefly tell the experience of openly discussing and practicing a narrative approach in the classroom and how students tended to engage (or not) with narrative as a way of making sense of their "I" in IR.
\end{abstract}

Key words: narrative, International Relations (IR), subalternization of knowledge, Edward Said, postcolonialism, methodology

For citation: De Oliveira, J. da S.C. (2020). Narrative and Critical Imaginations in IR. Vestnik RUDN. International Relations, 20 (1), 131-146. DOI: 10.22363/2313-0660-2020-20-1-131-146

Научная статья

\section{Нарративные и критические образы в международных отношениях}

\author{
Дж.С.К. де Оливейра \\ Папский католический университет Минас-Жерайс, Посос-де-Кальдас, Бразилия
}

\begin{abstract}
Нарративные подходы привлекают все большее внимание исследователей международных отношений. Одной из ключевых предпосылок данного подхода является рассмотрение разнообразных толкований и изучение противоречивости политики таким образом, чтобы рассматривать международные отношения как множественность мира(ов) в рамках мировой политики. Эта статья содержит анализ использования нарративных подходов к изучению международных отношений и связывает их с понятием «приземленности» Эдварда Саида, которое позволяет подчеркнуть политические аспекты литературных произведений и репрезентации в академических исследованиях. «Поворот к нарративу» помещается в более широкий контекст кризиса евроцентризма знаний и представлений о международных отношениях. Кроме того, в статье демонстрируется растущее значение демонстрации «Я» исследователя в научных текстах. Имея в виду общее стремление к более чутким отношениям между
\end{abstract}

\footnotetext{
* A previous version of this article was presented at the Brazilian Association of International Relations (ABRI) 2019 conference held at the Pontifical Catholic University of Minas Gerais (PUC Minas), Belo Horizonte, MG, Brazil, under the title "Narrative IR, Worldly IR: The Politics of the Recent Turn to Narrative Approaches in IR". Some parts of the argumentation were also developed in more depth somewhere else. See: De Oliveira J. da S. C. Postcolonial Maghreb and the Limits of IR. London: Palgrave Macmillan, 2019.
}

(C) De Oliveira J. da S.C., 2020

This work is licensed under a Creative Commons Attribution 4.0 International License.

https://creativecommons.org/licenses/by/4.0/ 
исследователем и предметом исследования, учеными и общественностью в целом, преподавателями и студентами, автор кратко излагает опыт открытого обсуждения и практики нарративного подхода в учебной аудитории, когда студенты проявляют тенденцию использовать (или нет) нарративный подход как способ осмыслить свое «Я» в изучении международных отношений.

Ключевые слова: нарратив, международные отношения, субальтернализация знаний, Эдвард Саид, постколониализм, методология

Для цитирования: De Oliveira J. da S.C. Narrative and Critical Imaginations in International Relations // Bectник Российского университета дружбы народов. Серия: Международные отношения. 2020. Т. 20. № 1. C. 131 -146. DOI: 10.22363/2313-0660-2020-20-1-131-146

The world of international politics is filled with narratives. When the US government justified its so-called war on terror after the September 11, 2001 attacks, they told a story so powerful that our view on the world is in many ways still imprisoned by it today [Campbell et al. 2007; Wibben 2011]. In an article published in 1987, feminist theorist Carol Cohn brings a brilliant and ground-breaking account on the practices and language deployed by nuclear defense professionals in a research centre and shows how this everyday politics is central to producing a particular way of thinking, talking about, and dealing with weapons, wars and people's lives, as well as to sustaining the US government's nuclear strategy itself [Cohn 1987].

Another interesting example in this sense can be found in Helle Malmvig's study exploring the contrasts in the language employed within the international community during the succession bloody events in two contemporaneous conflicts during the 1990s, one in a North African country, Algeria, and the other in an Eastern European country, Kosovo ${ }^{1}$. Focusing on the articulations of the concept of sovereignty by the international community and the different practices of either intervention (in Kosovo) or non-intervention (in Algeria) they entailed in each case, Malmvig [2006] manages to show the complex ways that discourse and political concepts evolve over time and vary according to circumstances of time and space. Thus, narratives serve to either encourage or undermine certain responses - as well as the political and ethical grounds on which they rely — in the international arena.

Narratives thus "tell us a lot about the limits and possibilities of political life" [Moulin 2016:

\footnotetext{
1 Russian Federation does not recognize Republic of Kosovo's independence (Editor's Note).
}

138]. As discipline, International Relations (IR) is built upon a set of narratives about the formation and expansion of the international system/society and how international actors perform their roles and actions within it. As Bartelson [1995], Inayatullah \& Blaney [2004], Walker [1993], and Weber [2001], to name a few, highlighted in their works, it seems only fair to suggest that IR is "product of competing and contesting narratives, some of which have become so dominant that they have... been taken to represent the sole explanation for the realities and nature of international political life" [Moulin 2016: 139].When reflecting upon the constraints to "our capacity to imagine" and speak of the world of international and global affairs and type of reactions they have generated in a certain corner of the discipline, Wanda Vrasti has recently summarized: "The stories IR likes to tell are often the same ones that we encounter in foreign affairs reporting and policy-making", these stories "deal with balance of powers, security alliances, and geopolitical calculations in a world of limited resources and thin sociality" [Vrasti 2017: 273].

The use of narratives strategies - ranging from autoethnography, autobiography, storytelling, fictional IR, among other approaches - has gained growing attention in the study of global politics [Brigg, Bleiker 2010; Dauphinee 2010; 2013a; 2013b; 2015; Doty 2004; 2010; Inayatullah 2011; Muppidi 2013; Park-Kang 2015; Shindo 2012; Vrasti 2010; Wibben 2011]. Along with this movement, stories other than the ones we hear from diplomats, politicians, mainstream media and IR theorists are brought to center stage in order to expose the myths shaping the world of international politics, as well as the violence and silences encouraged and perpetrated 
by those myths. One key promise in "Narrative IR" [Dauphinee 2013a] is mobilizing a diversity of interpretations and exploring the politics contestedness in ways that support the view of IR as a field focused on the multiplicity of the world(s) of international and global affairs.

As a method for both/either thinking IR and/or writing IR, narrative strategies might even assist researchers, teachers and students in making sense of what Edward Said would describe as the "worldly" aspects of IR theories and concepts - which, as we know, are sometimes excessively abstract, convoluted, and disconnected from particularities of time and space and the materiality of the world of global and international relations. The narrative "I" voice, for instance, has been adopted in many occasions as means to expose the researcher's own motivations and limits in what comes to knowledge production in general, and her relationship with her subject of research in particular. Moreover, these approaches also help to expose the narrative nature of truth claims when writing the political, encouraging deeper engagements not only with narratives as written, oral, or even sensorial substrata, but also with the political aspects of narratives as "knowledge stories".

This article aims to explore how the notion of narrative has been incorporated into the world(s) of IR. In the first section, I briefly discuss some of the epistemological and methodological implications of taking narratives seriously in the study of international and global affairs. In the second section, I connect this broad map, key concepts and problematizations regarding academic writing and the politics of representation with Edward Said's notion of "worldliness" in order to highlight the political aspects of narrative strategies within academia.

By reading what Dauphinee has called "Narrative IR" in parallel with Said's explorations of the relationship between the world and the text, one is able to situate this "turn" towards narratives within the complexities of a broader context of crisis in Eurocentric forms of representation and the subalternization of knowledge that came along with it. In this sense, the notion of "worldliness" allows us to better understand these reactions and the shared pursuit of a more empathetic relationship between researcher and researched, scholars and the public in general, teachers and students. Moreover, it assists us in addressing the anxieties, desires and ambivalences of those who have been openly deploying narrative approaches. In the last section, I briefly narrate the experience of openly discussing and practicing a narrative approach in the classroom and how students tend to engage (or not) with narrative as a way of making sense of and situating their "I" in IR.

\section{Narrative IR}

The politicization of language and textual practices is by no means new in the study of international and global politics ${ }^{2}$. Neither is the problematization of the interpretive categories that are key to social thought in general, including the study of international and global affairs, such as gender, class, race, power, state, ideology, to name a few ${ }^{3}$. Feminists, postcolonial and postmodern approaches have been pioneers in the deployment of a discursive approach and the articulation of alternative methodological strategies in their critiques of science, including, of course, Political Science and International Relations. Speaking from, and usually combining insights emerging at the intersections of the fields of Literature, Philosophy, Anthropology and Cultural Studies, to name a few, these critical voices problematize IR as a field of inquiry that "erase the political status of women, colonized and indigenous people, and racialized objects as being secondary, 'before' or 'outside' of normative state politics" [Vrasti 2017: 273]. The strategies and more particular aims of those approaches are manifold and as broad as the definitions one can provide for the term 'narrative' itself. However, a major point of connection among them seems evident in their

\footnotetext{
${ }^{2}$ In what concerns critical engagements with a discursive approach in IR, see, for example: [Campbell 1992; Der Derian, Shapiro 1989; Milliken 1999].

${ }^{3}$ In what concerns critical engagements with the tropes of class, gender and race in the study of international and global politics, for example, see: [Anievas, Manchanda, Shilliam 2015; Enloe 2004; 2014; Henderson 2013; Vitalis 2005; Wibben 2011].
} 
attempts at articulating epistemologies and methodologies that acknowledge the complexity, contingency, multiplicity and ambiguity of political realities.

In a brief mapping of the engagements with "critical methodological and narrative developments in IR" as resulting from the discussions during a workshop held in 2012 at the York University (Canada), Elizabeth Dauphinee [2013a] recalls how the sort of reflexive narrative approach inaugurated in feminist theorist Carol Cohn's 1987 article stood quite forgotten by IR scholarship for at least two decades. As Dauphinee observes, Cohn's narrative approach was widely acclaimed and cited, but "recognized mainly as a commentary on the limits of scholarship rather than as a legitimate scholarly contribution in its own right". I think Dauphinee was referring to Cohn's more radical reflexive attitude when adopting an autoethnographic stance - an innovative writing strategy in the field of IR in the late 1980s and to how she manages to expose aspects of her own position as researcher, drawing the reader's attention to the perks and pitfalls of her process of discovery rather than opting for a one-way road toward a conclusion that simply stresses the limits of academic enquiry.

As Vrasti highlights, the hyphenated triad ethnography-autoethnography-autobiography has been broadly mobilized in a number of interventions attempting "to come to terms with difference, subjectivity, and the desire of language" in engaging and writing IR. They are all examples of narrative approaches in IR and, although there are considerable differences among them - including how each of them is understood in the scope of particular research designs where they are employed, - sometimes they may overlap as academic writing genres in their attempts at "textual translation" of fieldwork and personal experience. Vrasti herself has been an advocate of ethnography as a participatory and dialogical mode of writing rather than mere methodology - specially in the more traditional meaning of the word - to be applied during fieldwork. In this perspective, although ethnography surely appears as a "process for organizing knowledge and communicating experience" whose methods can sometimes "look in places and pick up on details other methods would not register" - the reason why it became a darling among feminist, postcolonial and indigenous studies, to name a few, - it may also encourage "an extractive relation to the surrounding world" - as Vrasti cautions us. That is to say, it might fall into the same "documentalist" and truth-seeking "temptations" already present in realist anthropology and in conventional approaches to political science and IR [Vrasti 2017: 275].

The stance encouraged by Vrasti's narrative approach fosters research that reorients the questions of authority and subjectivity in international and global affairs through efforts that may start from questions as simple (and simultaneously ground-breaking) as "where are the women?" - as Cynthia Enloe [2004; 2014] has emblematically done in her work. Moreover, it may help to open up the field to "the multiplicity of unauthorized narrators and voices - collective, singular, fragmented and unsigned - that continue to creep in the cracks of the interstate relations" [Moulin 2016: 142]. In addition, it opens the ground to questions related to "narrative conventions" and to the "explanatory authority" of the researcher [Vrasti 2010: 87].

In other words, if we draw our attention to the politics of writing as Vrasti suggests, it becomes possible to address the relations between researcher and researched, narrator and narrative, and the ways they are linked to issues of power and authority. Interestingly enough, in doing so, it can open up possibilities to address the realms of restlessness, guilt, and even anger that may have led some critics towards a search for alternative truths - i.e. a truth of a very different nature than scientific truth.

Instigation around narratives as not only means of communication but also as appropriate material for academic knowledge in IR has been theme of recent academic forums and journals. To name a few, and as mentioned above, in 2012 the York Centre for International and Security Studies (Canada) held a workshop on "Critical Methodologies, Narrative Voice and the Writing of the Political: The Limits of Language". The 
reflections by some of the attendees was published in a mini-forum on critical methodlogies and narrative IR at the webpage The Disorder of Things. In 2010, Review of International Studies published a number of forum articles on the subject; and the same path was followed in 2016 by Crítica Contemporánea Revista de Teoría Política in the launching of a dossier on "Narrative (and) Politics" containing pieces in English, Portuguese and Spanish. New IR journals such as Critical Studies on Security (2013) and Critical Military Studies (2015) have maintained submission policies that accept fiction and poetry in their special sections. A space was also recently formalized in the Journal of Narrative Politics, an interdisciplinary publication sponsored by York University and edited by Elizabeth Dauphinee, Jenny Edkins, Naeem Inayatullah, Narendra Kumarakulasingam, Dan Öberg, and Paulo Ravecca.

Perhaps now one of the most militant voices among those advocating autoethnographic writing as one way to come to terms with the questions of power and authority between researcher and researched, as well as with the fictitious absence of the researcher's "I" in the academic text, Roxanne Lynn Doty alerts that "we lose our humanity when we write for the "discipline" [Doty 2004: 383]. As she problematizes, "the voice that echoes from our journals is all too often cold, detached, devoid of soul and human identity. As academic writers we have no personality on the page, no connection to the world of human beings" [Doty 2004: 381]. The absence of the self / "I" she mentions in academic writing is thus deeply political, since the series of exclusions and sanitizations occurring in this mode of detached, objective style of narration is nothing less than an unsuccessful attempt to conceal "the elusive thing called desire that lurks within all of us" [Doty 2004: 379].

In a nutshell, by calling attention to the artificiality and violence inherent to traditional academic writing in its efforts to erase emotions and the inevitable connections between the writer and the world she desires to reach/speak of/write about, Doty is making the case of the inherent political value of a movement towards what
Shapiro [1989] called "insurrectional textuality" instead. That is to say, to a "writing practice that is resistant to familiar modes of representation, one that is self-reflective enough to show how meaning and writing practices are radically entangled" [Shapiro 1989: 13]. The absence of the academic's "I" is (and can only be) fictitious, for "there is always voice in writing even if the voice is one of absence" [Shapiro 1989: 383].

Doty then highlights the potential of autoethnographic writing to shed light on the "other voices" in a text ${ }^{4}$. Doty's understanding of "other voices" relates to the possibility of writing in other ways that disrupt and differ from the emotionless style that prevails in academic writing. Doty's urge undoubtedly comprises "the need to transform academic international relations in a more inclusive intercultural dialogue that would... include voices from below, and ask[s] what such an inclusion could mean" [Doty 2004: $381]$.

Nonetheless, what seems to concern the author the most is the "other voices" of her own. That is to say, the voices that scholars are often encouraged to bury beneath the authority of the academic voice and "the sterility of the stories" they tell. More to the point, even though Doty states that opening the discipline to "other" voices in the sense of the numerous human beings who are excluded from is one step towards the more complicated path of "making connections in our writings" [Doty 2010: 1050], the movement she proposes may indeed sound as a search for the cure of "the maladies of our [academic] souls".

However, another possible reading of Doty's plea is that the healing process of the "maladies of our souls" must include the exposure of academic writing, theories and

\footnotetext{
${ }^{4}$ It is important to note that what Doty understands by "voice" does not necessarily refer only to an individual author, but rather to the text itself. As a scholar with a considerable poststructuralist background in most of her works, it seems quite unlikely that Doty would bring up the issue of voice as a feature of an individual author, for, as she herself points out, that would "pressupose the individual author/subject", which seems far from her intentions. On this specific matter, see, for example: [Foucault 1969/1984: 101-120].
} 
"scholarly identities" — which are largely defined by the absence of these "other voices" to a continuous commitment to "real people". "Real people" here would include not only ourselves, "who 'we' are and what 'we' are about as 'we' engage in 'our' scholarship" [Doty 2004: 381], but also those others who are subjects of representational practices within academic discourse. However, Doty seems to be much more focused on the "academic we/us" than on anything else.

The impetus in Elizabeth Dauphinee's approach to autoethnography is slightly different. Hers sounds as a more openly stated attempt to cope with the guilt and anger of having advanced her career on the backs of the Yugoslavian war. Dauphinee's now acclaimed book The Politics of Exile [2013b] comes across as a hybrid between a novel and an academic autoethnographic account wherein she traces her own encounter with her research subject - the Bosnian War and its aftermath. She narrates in an affective tone the impossible conundrums encircling and connecting the life of a young and insecure scholar (in the book, the unnamed professor of International Relations, probably Dauphinee's avatar) and the lives of the soldiers and civils involved in the bloody conflict she struggles to make sense of.

The opening paragraphs of Dauphinee's beautiful narrative gives us a glimpse of the impossible choices one has to face when in a researcher's position - one of the key subjects in a book that also reads as a story about the complexities of people's lives and the pains and hopes that both (and simultaneously) differentiate and connect us as human beings. The author herself would later describe her move away from the argumentative approach that predominates in her previous book The Ethics of Researching War [Dauphinee 2007] to a narrative constructed at the border of what could be defined as either novel, memoir, or even an autobiographical account as coming out of "a politics of hope" [Dauphinee 2013c]. In this sense, Dauphinee's approach to autoethnography seems to go further with Doty's initial urge for an intellectual ethics of encounter, that is to say, from a commitment to writing as an exercise at connecting with the "real" world. If the "world" to which Doty was referring is still confined to the multiple voices of our-selves as scholars in practices of academic writing, Dauphinee's approach touches upon "a deep and abiding awareness of the real difficulty of what that ethics attempted to do, which was to expose the researcher to the accusation of the researched in a way that recognized trauma while still resisting the meaning... [the researcher] hoped to find" [Dauphinee 2013c: 350].

Autoethnographic exercises in writing IR have shown that there is a great challenge in attempting to make sense of "all the many layers of reasons and motives" why we act or write. In later reflections on her 2013 book, Dauphinee alerts us that "prioritiz[ing] them in any fixed or trans-historical way" is also dangerous [Dauphinee 2013c: 349]. This is just another way of saying that "the 'I' always risks to stand for self / 'I' indulgence" that may terminate in replications of the distance between researcher and researched [Vrasti 2017: 278]; the "critic", her critique, and "the world". In this sense, autoethnographic writing can be embraced as a starting point for a deep analysis of the relationship between scholar-writers and the worlds they encounter and help to create. With the risk of becoming a matter of "self-indulgent purification" [Brigg, Bleiker 2010: 276], the hope that this sort of reflexivity awakes is that it can eventually "break the barrier and flatten the power relations that separates the academy from the people, communities and places it studies" [Vrasti 2017: 277].

Similar motivations and setbacks seem to haunt those few who dared to resort to autobiography as an alternative form of writing and means to face the erasure of the scholarwriter's personal voice and other complex aspects of people's stories in IR. Both autoethnographic and autobiographical writing are politically and emotionally engaged modes of writing operating in the interface between personal components and research expertise ${ }^{5}$. In

\footnotetext{
${ }^{5}$ In one footnote to his 2015 article Fictional IR and Imagination: Advancing Narrative Approaches, Sungju Park-Kang brings an insightful observation on how the
} 
autoethnographic accounts, however, the commitment "to make connections with others and the world" [Park-Kang 2015: 365] is often more explicit and demanding, especially in what touches the particular realm of the encounter between researcher and researched in the field, especially when the first starts writing the field (see: [Vrasti 2010; 2017]).

The collective project Autobiographical International Relations: I, IR edited by Naeem Inayatullah [2011] is exemplary of such movement. Inayatullah starts by telling us his own trajectory "towards the cliff of autobiography" [Inayatullah 2011: 1] and how other IR scholars' individual wanderings met one another in the collection of fifteen essays. As the author remarks, "academic writing supposes a precarious fiction", that is, that the author's absence is prerequisite for objective and scientific forms. The exposure of this "fictive distance" then becomes the string connecting the essays in the ways they demonstrate how personal narratives influence theoretical articulations, and how authors' "theoretical/ practical engagements" are not apart from "their needs and wounds" as human beings and political subjects [Inayatullah 2011: 5-6].

More recently, Naeem Inayatullah and Elizabeth Dauphinee co-edited a collection of essays following a similar line to the one taken in Inayatullah's volume on autobiography and IR. In the short introductory chapter to Narrative Global Politics - Theory, History and the Personal in International Relations [2016], the editors reinforce the "urgency" to put the "narrative question" at centre stage in its quality as a theoretical problem to academic writing and being in the world. Autobiography is just one among the narratological conundrums to be taken

issue of the "self" has frequently haunted academic publications across disciplines, and importantly enough, even those which are not even close to a conscious engagement with autoethnography and autobiography as scholarship. He writes: "Consider acknowledgements or prefaces of books (and sometimes articles). They usually reveal authors' struggles to publish, 'personal' stories, research networks/interlocutors, families and even lovers, all of which could constitute the above auto-scholarship to some extent" [Park-Kang 2015: 366, footnote 42]. seriously when writing the political from a global perspective. The lines between autobiography, autoethnography, or the more general notion of narrative itself are blurred and regarded as less important than the politics of writing IR itself.

Thus, conceiving IR accounts as political narratives rather than scientific and uncontested explanations allows one to not only expose aspects of "the myth function in IR theory" [Weber 2001: 7]. As advocates of such positioning have pointed out, by doing so, one is indeed allowed to improve scholarly research less in terms of achieving the truth about a world "out there" waiting to be impartially observed and assessed than in terms of the explanations and understandings aimed (see: [Suganami 2008]). Through this brief review of works that have remarkably adopted a narrative approach in IR, it is possible to infer that they share the belief (or at least the hope) that narrative methodologies allow IR researchers to rethink the "fictions" of academic truth, technical-prone writing, and language in a broad sense. In addition, it also allows researchers to reconsider the place of the political in IR, acknowledging the multiverse of loci of enunciation and action shaping global politics both from its centres of power and from its margins. In a similar fashion, it may encourage the adoption of a more reflexive and ethically-bound stance towards the research subject, as well as towards the scholar's own position as researcher and political subject herself.

Thus, there seems to be a double-edged movement of, on the one hand, a symptomatic disenchantment with the persisting shortcomings in the practices of knowledge production in IR as a field of inquiry; and, on the other hand, of a number of attempts at coming to terms with such discontent, in "a sort of re-enchantment of the world of global politics with a greater diversity of voices, characters and stories" [Vrasti 2017: 273]. In my view, it is in this double movement of scholarly disenchantment and re-enchantment that one may trace the growing interest in narrative approaches and alternative ways of writing in the field of IR (see: [De Oliveira 2020]). 


\section{Intellectual (Dis)Engagement and the World}

As argued above, the movement towards "Narrative IR" is offspring of the critical engagements and fierce criticism of how the discipline has been dealing with its object of knowledge, its linkages with strongly oppressive and state-oriented projects and world views, and its "provincial imagination" undeniably rooted in a history of global hierarchies [Muppidi 2013]. From this perspective, narratives are not only ontologically defining in the ways we perceive and act onto the world. Narratives also appear as productive strategies, a mode of knowing and questioning the prevalent dynamics and inherent violent traits of knowledge production and transmission within academia, and a nonindifferent attitude towards the audiences IR researchers are trying to reach. At stake here is not only an epistemological rupture with traditional positivist criteria of knowledge production, but the articulation of an ethicalpolitical commitment to shortening the distance between the institutionalized space of knowledge production that is academia and the world it tries to understand and speak of/to.

Edward Said has thoroughly explored the theme of (symptomatic) scholarly isolationism perhaps indifference - in his writings, especially in his later works addressing literary criticism from a perspective that highlights the connections between texts and the world they purport to represent. Said's notion of "worldliness", as well as his related discussion on what means to link text to context, knowledge to (the hope) of social change, and his plea for intellectual "wakefulness" - translated in the concept of "secular critical consciousness" — as an ethicalpolitical stance that is opposite to disembodied scholarly criticism are all particularly relevant in this sense. Of course, Said's insights should be taken up critically as well as situated. My only suggestion here is that some of his interventions may help us to better situate the motivations and operating forces — of either/both complicity and/or resistance - that have led to the movement towards narrative approaches in IR.

In his attempts to understand how the current elements of hegemonic cultural forms and authoritarianism could be addressed and resisted, the author draws attention to the ways "Western knowledge" - to use Linda Tuhiwai Smith's [1999] terminology — have constructed historical narratives that manage to establish limits to what is knowable, speakable, and desirable as such. Naturally, these limits also demarcate who is entitled to know and speak in the name of valuable knowledge. In The World, the Text and the Critic [Said 1983], for example, the author addresses some examples of "the canon" of modern European thought as "textual instances" of the ethnocentrism that had been complicit and continually reinforced the hegemonic culture behind European imperial and colonial enterprises - an effort that is analogous to the discussions he had inaugurated in Orientalism [Said 1978] and continued in later explorations.

An important point to be noted is that Eurocentric sciences and traditional academia establishes and constantly reinforces the circumstances and jargons under what critique must come into surface as the legitimate contradiction that is eligible to becoming valuable knowledge. In this sense, according to Said, the authority of this cultural system comes not only from its canons, its appearance of political neutrality - for it deals with the pursuit of objective, uncontested and detached "truth", its "camouflaging jargons" and institution of criticism, but also "from the way this continuity reproduces the filial continuity of the chain of biological procreation" [Said 1983: 22]. Even critique is an academic institution that can easily fall into "out-worldly" contemplative exercises, formalism, and professional opportunism encouraged by the very interpretive community where it belongs.

According to Said, the problem lies not in exercises on high theorization and abstraction themselves, which are indeed parts of the "academic thing", but in the unsurmountable disconnection that "camouflaging jargons" and "hermetic systems" tend to generate [Said 1983: 25-26]. Said then suggests two set of opposites to make his case for the adoption of a what he calls a "secular critical consciousness" as means to (re)connect scholarship to the world, and to 
conceive texts as significant political forms; in other words, to rethink texts - what, of course, includes academic writing - in their worldliness.

The notion of "secular critical consciousness", brings to the fore his emphasis on secularism - the "worldliness" of cultural and social forms. It relates with the mindset that "human beings make their own history" [Said 2001: 501, quoted in Giroux 2004: 345] and, for that very reason, that one must "recognize the multiple sites in which a mindless appeal to scripture, divine authority, and other extrasocial forms of dogmatism... undermine the possibility of human agency" [Giroux 2004: 345]. Evidently, one may also include amidst "extrasocial forms of dogmatism" all those complex theoretical discourses that drain out the worldliness of texts, language, and public life.

Thus, Said's notion of secular critical consciousness cannot but be intimately connected to a "politics of crisis", as Henry A. Giroux (after Sheldon Wolin) suggests. The urgency that the notion of crisis brings to surface implies a call to "connect matters of knowledge and scholarship to the worldly space of politics" as means to oppose "a concept of criticism among many academics, which implies a narrowing of the definition of politics and an inattentiveness to the public space of struggle, politics, and power" [Giroux 2004: 339].

Said's understanding of "individual consciousness" and its proneness to bringing about change seems to be less about individual subjects than a social force in itself. It is invariably embedded in the cultural system where the dynamics of affiliation takes place. Therefore, agency here may tend toward either resistance or complacency. The terms of resistance, in turn, may operate either from within the limits of the established language and its replication — which can often disguise as deep critique and significant change of order whereas it is actually none - or from attempts to carving out a language of itself ${ }^{6}$. This is where

\footnotetext{
${ }^{6}$ Some aspects of Said's argumentation regarding the different forms that criticism can assume resembles the differentiation that Walter Mignolo's suggests between critical approaches articulated from inside Eurocentrism what Enrique Dussel characterized as a "Eurocentric cri-
}

Said discusses the differences between "the critic" and "the public intellectual". Ultimately, the role of the public intellectual is not to consolidate authority of any kind but to understand, interpret and question it in meaningful, worldly ways.

This intimate connection between the role and responsibility of the public intellectual and secular criticism in Said appears even more clearly, for instance, in his engagements with the work of Frantz Fanon, the Martinique-born leading theorist of the Algerian revolution. In Les Damnés de La Terre [The Wretched of the Earth], Fanon's now classic statement against colonial domination and its capillarities, anticolonial resistance concerns not only with the immediate need for independence from the foreign colonial occupier, but also, and importantly, with liberation from a nationalist

tique of modernity" - and the critique articulated from the interstices of colonial difference, i.e. "decolonial" approaches. The latter can be more closely related to what Dussel and others have pursued, that is, a project of intellectual liberation from Eurocentric social sciences which does not emerge from inside Eurocentrism and modernity, but from tensions that the Eurocentric border is not able to capture within its logic to either incorporate or simply exclude; that is to say, they point towards the critique that emerges from its exteriority and that does not presuppose Eurocentrism as totality. As Mignolo [2008] explains (borrowing insights from Dussel's work more specifically, but also from Aníbal Quijano's, Orlando Fals-Borda's, and Abdelkebir Khatibi's, to name a few), this philosophy of liberation stemming from colonial difference stands for a delinking from the tendency toward Eurocentric critiques of Eurocentrism (e.g. poststructuralism, world-systems analysis) while taking coloniality and colonial difference into serious account both as constitutive components of modernity and (importantly) as loci of enunciation. It is aimed at not only turning visible the "variety of local histories that Western thought, from the Right and the Left, hid and suppressed" - a move that can turn out to "reproduce the blind epistemic ethnocentrism that makes difficult, if not impossible, any political philosophy of inclusion" beyond Eurocentrism, - but also at contributing to the reinscription of experience and "the making of diversality" (as opposed to "a new abstract universal project") [Mignolo 2008: 234, 256-257]. According to Mignolo, it is an effort that includes discontinuity, crisis and (colonial) difference as key in the pursuit of "a network of planetary confrontations with globalization in the name of justice, equity, human rights, and epistemic diversality" [Mignolo 2008: 256]. 
bourgeoisie that perpetuates the subjugation of subaltern groups within the former colony.

According to Fanon, without a transition from an undiscriminating nationalist consciousness to a deeper social and economic awareness, the oppressive nationalist elite remains entrenched and the postcolonial society stays permanently trapped in a peripheral position in the world system. In that matter, it is worth noticing that Fanon understands this revolutionary, deeper awareness, in terms of a universal humanist socioeconomic consciousness that stands in clear opposition to, and as a reaction against, the contradictions in European universalist discourse. And that's precisely why, according to Fanon, resistance must be a bifocal enterprise: a nationalist struggle against the colonial invader and a universal struggle against the bourgeoisie [Fanon 1963/2004]. In this aspect, Said seems to take Jean-Paul Sartre's reading of Fanon in the preface to The Wretched into serious account. There, Sartre wrote that, from a Fanonian perspective, "the only true culture is that of revolution; that is to say, it is constantly in the making" [Sartre 1963/2004: 12].

Once again, the politics of crisis is brought to the front line, since crisis here could read as another description for being "constantly in the making"', and thus attentive to the public space of struggle, politics, and power. In what concerns the space of knowledge production and knowledge narratives (which are Said's main focus), feelings of unease and uncertainty in the face of the worldliness of human relations and aspirations thus appear as a productive force, nurturing critical consciousness while preventing closure.

While Said is undoubtedly inspired by Fanon's account on the connection between the

\footnotetext{
7 The passage is quoted as it appears in the 1963 translation of Les Damnés de la Terre (1961), by Constance Farrington. My choice for maintaining the words as they appear in that previous edition was simply to remain faithful to Said's engagement with Fanon's work, in which the idea of revolution as something "constantly in the making" is crucial. In the 2004 translation by Richard Philcox, for example, the same passage from Sartre's preface to Fanon's book reads: "The true culture is the revolution, meaning it is forged while the iron is hot" [Fanon 1963/2004: xlvii].
}

need for a critical consciousness and decolonization, the latter brings an important counterpoint to Said's depiction of the postcolonial/diasporic/public intellectual as the main mediator, or perhaps the incarnation, of this revolutionary culture in the making. In fact, Fanon is deeply critical of the ambivalent position of the colonized intellectual who is caught between the experience of colonization and he called "the famous dialogue on [Western] value" to which he/she is inevitably attached due to his/her education [Fanon 1963/2004: 9]. Thus, there would be a significant distance between Said's and Fanon's ultimate answer to the question: if the only true culture is a revolution always in the making, who are the true revolutionaries? ${ }^{8}$

Although both Fanon's obstinate judgement of the colonized intellectual and Said's almost uncontested faith in the figure postcolonial (diasporic) public intellectual may come across as precipitated, I find Fanon's suspicion regarding the proximity to Western values is worthy to bear in mind. It signals towards an important dimension in grasping the unequal relationship between the intellectual and the others he/she claims to represent - i.e. subaltern subjects, such as migrant workers, women (especially non-Western women), peasants, etc.

However, I do find Said's point regarding the importance of thinking beyond matters of "survival" in contexts of political unrest and struggles for liberation compelling. On the one hand, it draws attention to the problem of intellectual disengagement towards grass-roots emancipatory projects and viewpoints, specifically, and towards the world he/she claims to engage in knowledge narratives, in general. On the other hand, there is a value in Said's perception that the intellectual must have in mind the ethical-political implications of his/her positioning in what regards social movements

\footnotetext{
${ }^{8}$ If in Said there is a certain ambivalence towards this answer, and intellectual critical imagination often seems to somehow precede or at least walk side by side with grassroots political struggles, for Fanon, the answer is straightforward: the peasantry (which appears as the ultimate consciousness of the colonized intellectual). See: [Fanon 1963/2004].
} 
and struggles, which, of course, must also include committed meditations on the forms of domination and tyranny that might emerge out of these alternative, once marginal sites and worldframings. Therefore, the need for an "ironic" attitude against any and all forms of tyranny and domination - even when claimed as resistance [Said 2001].

Thus, another key dimension of the worldliness of critique that Said emphasizes translates as an ethical-political stance (by the public intellectual) that manages to put knowledge, first and foremost, in service of humanity beyond privileged spaces — such as Western knowledge, academia, and institutional politics. The point here is not that all intellectuals must embrace the role of political activists in the traditional sense of the term, altogether. It relates more to the ethical-political value behind a constant exercise of critique that includes selfcriticism as one of its key dimensions, yes, but remains vigilant against solipsism and "synoptic knowledge" - which, as Sankaran Krishna [1993] came to alert us, are both symptoms of the ethics of otherness adopted by critical approaches too focused on textuality, on practices of representation and signification, while remaining inattentive to the "physicalistic sense of violence" that accompanies contexts of material and epistemic inequality in international and global relations. Ultimately, it connects the cognitive-political craft that academia must be/become, with an open attitude toward the multiverse of worldviews and modes of political action acting upon the world.

Therefore, if on the one hand Said's approach to culture seems to suggest that dominant discourses are incapacitating ad infinitum in their persistence and replication, on the other hand, he also attempts to show that hegemony necessarily finds its limits when confronted with the complexity of social experience. Paradoxically, by trying to suppress complexity, the hegemonic culture actually leads to the emergence of fissures and the strengthening spaces for imagining alternative orders and enacting opposition. Here, one can find elements of the politics of hope that Dauphinee [2013c] talks about and which is embedded in her attempts to come to terms with her research and her privileged position as an intellectual and IR scholar.

Hope towards change - and toward the possibility of playing a meaningful role at least in the process of envisioning change - is an important feature in what I understand as a trendy "re-enchantment" with the multiple worlds of international and global politics in current critical approaches to IR (narrative approaches among them). Nonetheless, the remaining question (and difficulty) is always whether these high hopes can translate into concrete platforms and "resources to people in and out of the academy who struggle on multiple fronts against the rising forces of authoritarianism both at home and abroad", or somewhere in between [Giroux 2004: 345].

As scholars interested in this alternative approach (for some, methodology) have pointed out, with the promise of a more inclusive IR, there are also the dangers of transforming this "narrative turn" into a romanticised frame for subaltern voices and subjectivities and in gestures based on intellectual guilt rather than on the desire (and courage) to open spaces for genuine dialogue and different or even opposing worldviews [Muppidi 2013]. The line between the potential transformation and democratization of spaces for knowledge production and mere "exercises of self-indulgence" excessively focused on "personal and confessional without a sustained political motive" [Dauphinee 2013a] is, therefore, very tenuous.

\section{Narratives in the Classroom: Reflections on Narrative Approaches, Critical Imaginations and the "I" in IR}

Narrative IR starts with the assumption that narratives provide ways of contributing to critical engagements and movements of re-reading IR's common places and authoritative voices. It highlights important aspects of power-knowledge conundrums and allows room for (re)imagination. Once I mention this potentiality of taking narrative and writing into seriously account and, relatedly, the possibility of mobilizing writing styles other than one loaded with academic 
jargon and a desirable writer-reader/researcherresearched split, I notice student's spontaneous excitement. Of course, excitement here should be qualified as ranging from curiosity to suspicion, and from embrace to resistance (sometimes followed by strong refusal). "The related issues of voice and academic writing", I start telling them, "once only ghost matters in our field, have been moved to the forefront of a debate in which academic subjectivity (one dimension of the "I" in "IR") is questioned".

The experiences briefly described here were originally thought as mere complementary activities to spice up methodology classes and, hopefully, bring students closer to their research themes - which, as we know, can easily pass as sanitized and "out-world" field of inquiry. This way, neither the activities proposed nor the questions I brought up in class to stimulate the students to expose their perceptions were completely structured beforehand. In addition to open discussions in class about the question of narrative in scholarly life, undergraduate students assigned in my Methodology II course focused on methodological approaches after the "Reflexivist turn" in IR (see: [Jackson 2011; Luceli, Sula 2016]) — were encouraged to perform two different activities, one individually, at home, and the other collectively, in class.

For the first activity, students were asked to make an assessment of the narrative strategy and reflect upon the methodological and political (!) implications of such strategies after reading Elizabeth Dauphinee's The Politics of Exile. The second activity, in turn, was an open group discussion in which students were firstly encouraged to talk about "the place of the 'I' when one is thin-king/doing IR", and, secondly, asked to articulate about the connections and disconnections between their individual life experiences and the themes they have chosen for monography projects.

Generally speaking, the first activity was marked by two major trends. On one side, there was a number of students simply marvelled at the young professor's trajectory in Dauphinee's book after she meets the mysterious man who not only embodies her very object of research, but also carries an alternative perspective on everything upon what she built her academic career. As one student brilliantly observed, one way of interpreting the plot is understanding it as the process of a young researcher becoming a "reflexivist" regarding her object of study and the very field of IR. On the other side, there was another major trend: students who focused specifically on the personal relationship between the young professor and the Serbian excombatant.

Within this group, there was a relatively small number of students who confessed their difficulty in connecting the narrative in the book with IR as a field of knowledge. For most of these students, it seems, the events narrated by the professor in Dauphinee's book evolved as a "closed" reality, a particular case not necessarily connected to or symptomatic in the task of thinking/doing/writing international politics.

One remarkable comment made by one student was that she could not help seeing IR themes and research objects as "a distant reality", something "external and hardly reachable, specially for undergrads who... you know... undergrads like us!". Even though the student never completed her sentence, I can only hypothesize that she meant something like "undergrads who grew up in the countryside of Brazil", "undergrads who have never travelled outside the country so far", or, perhaps, "undergrads who have just begun making sense of the world(s) of international and global politics". In this same regard, another - perhaps less pessimistic - student pointed that she was convinced by Dauphinee's book that it is possible to empathize with "distant others" and, thus, starting thinking of them as subjects, individuals with life trajectories and experiences of their own rather than simply distant objects of study.

The second activity was conducted during class. The topic of the class was "the place of the 'I' in IR" ("o lugar do eu nas RIs", in Brazilian Portuguese) and students were asked beforehand to reflected about their connection with their research themes and the relationship between their life experience and their choice of studying IR in general. I decided to be the first one to speak in order to break the ice and, hopefully, 
transmit what I intend to be a mix of confidence and solidarity to the group. Results were mixed in all the three times I taught this specific class - with three different student groups. From what I noticed, students were more prone to open themselves to reflection and to share parts of such reflections with their colleagues when there was a sense of bonding among most of them, i.e. a "we feeling" as a group.

In all three sections - conducted with three different groups of students throughout the three consecutive semesters I taught Methodology II there was quite an equilibrium in the number of students who were able to articulate without resorting to academic jargon and those who had to resort to concepts and theories in order to explain their research choices and make themselves clear to the others. Whereas most students within the second major trend mentioned that they did not see a direct connection between their life experience and choosing IR as profession or a specific subject as research theme; students who were more successful in articulating what they thought to be their "I" in "IR" even mentioned that narrating to colleagues their reflections was more helpful than shameful and that it was a fruitful exercise in motivation to pursue their research projects. Some students mentioned that they have realized that studying and thinking IR was more a way of coping with specific parts of their life stories than anything else. A number of them even connected the idea of the "international" with the aim of being away from home.

In one of the sections, one student mentioned that after putting herself into this guided reflection, she could think of IR as something closer to her and beyond the image of academia and the "science" of analysing international politics. A few of them also connected their choice for IR and their current research theme as a way of being professionally successful - and, curiously enough, "being successful" was sometimes portrayed as a synonym of working and making a life abroad.

As one might expect, there was a number of students adopting a more skeptical — sometimes genuinely indifferent — attitude regarding the role of narrative in academic research.
Nonetheless, during the three sections of these same two activities involving students' engagements with narrative IR, most students reported in various ways how they became more aware of their situation (some would call "positionality") as IR students and, thus, could start perceiving the tasks of thinking and writing IR as "worldlier" experiences after performing these exercises in Narrative IR.

\section{Concluding Remarks}

This article was aimed at exploring some of the epistemological and methodological - and, I would add, ontological - implications of taking narratives seriously in the study of international and global affairs. Said's insights regarding the worldliness of texts helped to highlight the connection between text and context, and to understand the gap that scholars resorting to narrative approaches are trying to fill.

Conceiving IR as a field of knowledge and of IR theory itself as a "ensemble of stories" we tell about the world [Weber 2001: 129-130] appears as the fundamental assumption for those engaged with the discursive aspects of world politics and with narrative approaches in IR. In this sense, as Michael Shapiro argued almost three decades ago, what seems to be at stake in the narrative turn is "a change in the self-understanding that constitutes the field of social and political analysis", in which "part of what must be rejected is that aspect of the terrain predicated on a radical distinction between what is thought of as fictional and scientific genres of writing" [Shapiro 1989: 7, quoted in Wibben 2011: 46].

The attention to how narratives make the world of international relations and, relatedly, the more emphatic turn to narrative approaches in IR thus address the politics of representation in the field in more than one dimension: i.e., what/who we understand to be within the realm of international and global studies (what is the world of international affairs); the terms under which episodes, voices and practices are deemed relevant in different world-framings within the discipline; and, more generally, how rethinking all these aspects in terms of representation reorients and complicates not only the way we 
understand global politics but also the very practice of narrating the international and the global as politically relevant. Among other things, such movement might open up spaces for reimagining IR (and its objects of knowledge) from other locations besides the great centers of knowledge production and decision-making one necessary step towards the search for decolonizing IR and other fields.

The last section of the paper tells the experience of teaching an IR Methodology course by using a narrative approach and focusing on questions regarding the place of the "I" in IR. Although results were mixed in terms of the number of students willing to connect with the activity and the task of thinking the connections and disconnections between their life experiences and their trajectory as IR students as well as their place as subjects in the world(s) of international and global relations, the overall outcome of the activity - from both the student groups' reports on the activity and my own point of view - was the possibility of opening spaces for reflections on positionality, theories and disciplines - and borders between disciplines - as knowledge stories/narratives in themselves, and academic research and writing as autobiographical endeavors. Opening up spaces for such themes and exercises in the classroom can pave the way for the "pluriversal" IR some scholars have been advocating for (see: [Blaney, Tickner 2017]), as it makes room for unauthorized voices and world frames to emerge - may they be of small groups of young students in Brazil or of other subjects and groups in different parts of the so-called Global South.

Received / Поступила в редакцию: 12.01.2020 Accepted / Принята к публикации: 06.02.2020

\section{References / Библиографический список}

Anievas, A., Manchanda, N. \& Shilliam, R. (Eds). (2015). Race and Racism in International RelationsConfronting the Global Colour Line. London \& New York: Routledge.

Bartelson, J. (1995). A Genealogy of Sovereignty. Cambridge: Cambridge University Press.

Blaney, D. \& Tickner, A. (2017). Worlding, Ontological Politics and the Possibility of Decolonial IR. Millenium: Journal of International Studies, 45 (3), 293-311. DOI: 10.1177/0305829817702446

Brigg, M. \& Bleiker, R. (2010). Autoethnographic International Relations: Exploring the Self as a Source of Knowledge. Review of International Studies, 36 (3), 779 - 798. DOI: 10.1017/S0260210510000689

Campbell, D. (1992). Writing Security: United States Foreign Policy and the Politics of Identity. Minneapolis: University of Minnesota Press.

Campbell, D., Bialasiewics, L., Elden, S., Graham, S., Jeffrey, A. \& Williams, A.J. (2007). Performing Security: The Imaginative Geographies of Current US Strategy. Political Geography, 26, 405-422. DOI: 10.1016/ j.polgeo.2006.12.002

Cohn, C. (1987). Sex and Death in the Rational World of Defense Intellectuals. Signs, 12 (4), 687-718.

Dauphinee, E. (2010). The Ethics of Autoethnography. Review of International Studies, 36 (3), 799-818. DOI: $10.1017 / \mathrm{S} 0260210510000690$

Dauphinee, E. (2007). The Ethics of Researching War: Looking for Bosnia. Manchester University Press.

Dauphinee, E. (2013a). Critical Methodological and Narrative Developments in IR: a Forum. URL: https://thedisorderofthings.com/2013/03/12/critical-methodological-and-narrative-developments-in-ir-a-forum/ (accessed: 11.11.2016).

Dauphinee, E. (2013b). The Politics of Exile. London \& New York: Routledge.

Dauphinee, E. (2013c). Writing as Hope: Reflections on the Politics of Exile. Security Dialogue, 44 (4), 347-361. DOI: $10.1177 / 0967010613492838$

Dauphinee, E. (2015). Narrative Engagement and the Creative Practices of International Relations. In: Steele, B.J. \& Amoureux, J. (Eds.). Reflexivity and International Relations: Positionality, Critique, and Practice. London: Routledge. P. 44-60.

De Oliveira, J. da S.C. (2020). Postcolonial Maghreb and the Limits of IR. London: Palgrave Macmillan.

Der Derian, J. \& Shapiro, M. (Eds.). (1989). International/Intertextual Relations: Postmodern Readings of World Politics. Lexington, MA: Lexington.

Doty, R.L. (2004). Maladies of Our Souls: Voice and the Writing of Academic International Relations. Cambridge Review of International Affairs, 17 (2), 377-392. DOI: 10.1080/0955757042000245951 
Doty, R.L. (2010). Autoethnography — Making Human Connections. Review of International Studies, 36 (3), 1047-1050. DOI: 10.1017/S026021051000118X

Enloe, C. (2004). The Curious Feminist: Searching for Women in a New Age of Empire. Berkeley \& Los Angeles: University of California Press.

Enloe, C. (2014). Bananas, Beaches and Bases: Making Feminist Sense of International Politics. Berkeley: University of California Press.

Fanon, F. (1963/2004). The Wretched of the Earth. New York: Grove Weidenfeld.

Foucault, M. (1969/1984). What is an Author? In: Rabinow, P. (Eds.). The Foucault Reader. New York: Pantheon Books. P. 101-120.

Giroux, H.A. (2004). Edward Said and the Politics of Worldliness: Toward a "Rendezvous of Victory". Cultural Studies/Critical Methodologies, 4 (3), 339-349. DOI: 10.1177/1532708603262783

Henderson, E.A. (2013). Hidden in Plain Sight: Racism in International Relations Theory. Cambridge Review of International Affairs, 26 (1), 71-92. DOI: 10.1080/09557571.2012.710585

Inayatullah, N. \& Blaney, D. (2004). International Relations and the Problem of Difference. New York/London: Routledge.

Inayatullah, N. (2011). Falling and Flying: an Introduction. In: Inayatullah, N. (Eds.). Autobiographical International Relations - I, IR. London \& New York: Routledge. P. 1-12.

Jackson, P.T. (2011). The Conduct of Inquiry in International Relations. London \& New York: Routledge.

Krishna, S. (1993). The Importance of Being Ironic: A Postcolonial View on Critical International Relations Theory. Alternatives, 18, 385-417. DOI: 10.1177/030437549301800306

Luceli, C. \& Sula, E. (2016). Survival 'Beyond Positivism'? The Debate on Rationalism and Reflectivism in International Relations Theory. Politikon Journal of Political Science, 30, 43-55. DOI: 10.22151/politikon.30.3

Malmvig, H. (2006). State Sovereignty and Intervention: A Discourse Analysis of Interventionary and NonInterventionary Practices in Kosovo and Algeria. London \& New York: Routledge.

Mignolo, W. (2008). The Geopolitics of Knowledge and the Colonial Difference. In: Moraña, M., Dussel, E. \& Jáuregui, C.A. (Eds.). Coloniality at Large - Latin America and the Postcolonial Debate. Durham \& London: Duke University Press. P. 225-258.

Milliken, J. (1999). The Study of Discourse in International Relations: A Critique of Research and Methods. European Journal of International Relations, 5 (2), 225-254. DOI: 10.1177/1354066199005002003

Moulin, C. (2016). Narrative. In: Mhurchú, A.N. \& Shindo, R. (Eds). Critical Imaginations in International Relations. London/New York: Routledge. P. 136-152.

Muppidi, H. (2013). Reflections on Narrative Voice. URL: https://thedisorderofthings.com/2013/03/23/reflectionson-narrative-voice/ (accessed: 07.05.2017).

Park-Kang, S. (2015). Fictional IR and Imagination: Advancing Narrative Approaches. Review of International Studies, 41 (2), 361-381. DOI: 10.1017/S0260210514000291

Said, E. (1978). Orientalism. New York: Vintage Books.

Said, E. (1983). The World, the Text and the Critic. Massachusetts: Harvard University Press.

Said, E. (1994). Culture and Imperialism. New York: Vintage Books.

Said, E. (2001). Beginnings. In: Viswanathan, G. (Eds.). Power, Politics, and Culture - Interviews with Edward W. Said. New York: Vintage Books. P. 3-38.

Sartre, J. P. (1963/2004). Preface. In: Fanon, F. The Wretched of the Earth. New York: Grove Weidenfeld. P. xliii-lxii.

Shapiro, M. (1989). Textualizing Global Politics. In: Der Derian, J. \& Shapiro, M. (Eds.). International/Intertextual Relations - Postmodern Readings of World Politics. New York: Lexington Books. P. 11-22.

Shindo, R. (2012). Rethinking Community: Translation Space as a Departure from Political Community. International Political Sociology, 6 (2), 149—164. DOI: 10.1111/j.1749-5687.2012.00156.x

Smith, L.T. (1999). Decolonizing Methodologies: Research and Indigenous People. London \& New York: Zed Books.

Suganami, H. (2008). Narrative Explanation and International Relations: Back to Basics. Millennium - Journal of International Studies, 37 (2), 327-356. DOI: 10.1177/0305829808097643

Vitalis, R. (2005). Birth of a Discipline. In: Long, D. \& Schmidt, B.C. (Eds.). Imperialism and Internationalism in the Discipline of International Relations. New York: SUNY Press. P. 159-181.

Vrasti, W. (2010). Dr. Strangelove or How I Learned to Stop Worrying about Methodology and Love Writing. Millenium: Journal of International Studies, 39 (1), 79-88. DOI: 10.1177/0305829810371017 
Vrasti, W. (2017). Ethnography/Autoethnography/Autobiography. In: Guillaume, X. \& Bilgin, P. (Eds.). Routledge Handbook of International Political Sociology. London/New York: Routledge. P. 272-280.

Walker, R.B.J. (1993). Inside/Outside: International Relations as Political Theory. Cambridge: Cambridge University Press.

Weber, C. (2001). International Relations Theory: A Critical Introduction. London/New York: Routledge.

Wibben, A.T.R. (2011). Feminist Security Studies: A Narrative Approach. New York: Routledge.

About the author: De Oliveira Jessica da Silva C. - PhD (International Relations), Lecturer, the Department of International Relations, Pontifical Catholic University of Minas Gerais, Poços de Caldas (PUC Minas Poços de Caldas) (e-mail: jessicascoliveira@gmail.com, jessicas@pucpcaldas.br).

Сведения об авторе: Де Оливейра Джессика да Силва К. — доктор философии (международные отношения), преподаватель, факультет международных отношений, Папский католический университет МинасЖерайс, Посос-де-Калдас (e-mail: jessicascoliveira@gmail.com, jessicas@pucpcaldas.br). 